DOI: 10.20520/Jel-Kep.2014.4.21

\title{
Karafiáth Balázs
}

\section{A MEMETIKA ELMÉLETIKÖRNYEZETE}

Napjaink memetikai megközelítéseinek alapját az univerzális darwinizmus elfogadása és a dawkinsi elmélet adja. Az univerzális darwinizmus lényege az evolúciós struktúrában való értelmezés: a memetika szempontjából a legfontosabb, hogy ha van egy másolódásra képes egység, egy replikátor, és a másolódásnak van bizonyos jellegü „hüsége” (nem százszázalékos: van lehetőség változásra vagy hibára az evolúciós mechanizmus során), valamint adott egy olyan környezet, amely szelektál ezek közül a változatok közül, akkor az evolúció elkerülhetetlen.

Richard Dawkins Az önző gén címü könyvében (1976) vetette fel, hogy a kultúrában is lehetnek a génekhez hasonlónak tekinthető, replikálódó alapegységek: ezeket mémeknek nevezte el. Dawkins tehát genetikai analógia mentén tekint azokra a replikálódó alapegységekre, melyek a kultúra fejlődését, elemeinek szelekcióját és öröklődését támogatják. A kultúra evolúciója, akárcsak a nyelvé, gyorsabb léptékü, ezért változásait egy emberéleten belül is követhetjük. „A ruházkodási és táplálkozási divatok, a ceremóniák és szokások, müvészet és építészet, mérnöki tervezés és technológia, mind úgy alakultak ki a történelem folyamán, hogy kialakulásuk erősen felgyorsult genetikai evolúciónak látszik, de valójában semmi köze sincs a genetikai evolúcióhoz" (Dawkins 1986).

Mérő (2007) mutat rá arra a memetika kapcsán, hogy az a képesség, hogy az emberi elmében ébren vagy alvás közben absztrakt gondolatok jönnek létre, melyek közül sokat a kommunikáció folyamata során meg is oszt másokkal, kiemeli az embert a Földön élő fajok közül. Jelenleg csak az ember bír ezzel a mentális folyamattal: ez a folyamat ad teret a mémek létezéséről és vizsgálatáról való gondolkodásnak is. E cikk tárgya az ember és az emberi elme, ám fontos megjegyezni, hogy kutatások zajlanak a főemlősök (majmok, bálnák) és egyes énekes madarak (Blackmore 2001: 49) kultúrájának feltárása érdekében is különös tekintettel a horizontális és vertikális (generációk közötti) kultúra-terjedésre. Bálna dalok divatjával több kutatás is foglalkozik ${ }^{1}$ amelyek horizontális transzmisszióra utalnak. A majmok kultúrájának komplexitásával foglalkoznak Goodall és társai akik 39 különféle eszközhasználati, udvarlási és kurkászási szokást különböztettek meg ${ }^{2}$. Mindezek alapján elképzelhetö egy memetikai kutatási program a föemlösök körében is.

Dawkins az általa leírt replikátor-jelenségnek ragadós (erős, mert „fertőző” mém) nevet adott. A mára több tízmillió Google-találattal jellemezhető tudós szerint ,a mémek úgy terjednek a mémkészletben, hogy agyból agyba költöznek egy olyan folyamat révén, melyet

${ }^{1}$ http://www.uq.edu.au/whale/culture illetve

http://www.sciencedirect.com/science/article/pii/S0960982211002910 (Mindkettő letöltve utoljára 2014 október 7.)

2 A. Whiten, J. Goodall et al: Cultures in chimpanzees. In: Letters to Nature. Nature 399, 682-685 (17 June 1999) | doi:10.1038/21415 
tág értelemben utánzásnak nevezhetünk" (Dawkins 1986: 241). Dawkins - a genetikai megközelítés miatt - úttörö jellegünek tekinthetö felvetése a mémeket, mint kognitív vagy viselkedési mintákat kulturális replikátoroknak tekinti. Megfogalmazása alapján mém lehet „egy dallam, egy gondolat, egy jelszó, ruhadivat, edények készítésének vagy boltívek építésének módja" (uo.).

Dawkins fogalma hamarosan bekerült a szótárakba is. Az Oxford English Dictionary szerint a mém: „a kultúra olyan eleme, amely feltehetően nem-genetikai úton, például imitáció útján terjed". ${ }^{3}$ A hetvenes évek vége óta, Dawkins nyomán született memetikai elméletek közös pontja az elméről elmére, agyról-agyra zajló terjedés. Ha érdekes információ jut el hozzánk, gyakran előfordul, hogy nem sokkal a befogadást követően továbbadjuk, integrálva az interakcióba és a gondolatrendszerünkbe egyaránt. Ez korántsem jelenti azt, hogy az adott gondolati egység mindörökre kapcsolódik a belső struktúrákhoz: elképzelhető az is, hogy hamarosan passzív elemmé válik. Dawkins a genetikai analógiát leginkább azzal hangsúlyozza, hogy a mémek feladata - az ,önző génekhez” hasonlatosan - mindössze annyi, hogy minél több agyba jussanak el az utánzás folyamán. Bizonyos mémek terjedékenyebbek a többinél: Dawkins a longevity (élettartam), a fecundity (termékenység) és a copying-fidelity (a másolás megbízhatósága) tulajdonságokat adja meg a mémek túlélése kapcsán.

Ennek jegyében a mémek, mint replikátorok az egyetemes darwinizmus mindhárom kritériumának megfelelnek:

- Hosszú életủek, azaz viszonylag sokáig változatlan formában fenn tudnak maradni.

- Szaporák, azaz gyorsan és hatékonyan létre tudnak jönni újabb és újabb példányaik.

- Pontosan másolódnak, de nem túl pontosan, azaz az új példányok nagy, de azért nem százszázalékos valószínúséggel azonosak az eredetivel.

Mérő szerint Dawkins kutatásai azt mutatták ki, hogy az evolúció valójában a génekre, illetve a mémekre hat: az élőlényekre, illetve a gondolatokra csak rajtuk keresztül. Ahogyan a gének létrehozzák az élőlényeket, ugyanúgy a mémek is létrehozzák az eszméket, a gondolatokat (a vírusoktól az elefántokig, illetve a szellemi vírusoktól a brand-ekig vagy akár a vallásokig). Mindannyian a testünket alkotó gének, illetve a szellemünket alkotó mémek túlélögépei vagyunk. ${ }^{4}$

Az általános darwinizmus értelmében a minden területen észlelhető fejlödés a világ reprezentációjának generációk közötti evolúcióját is eredményezi. Laland és Brown (2002) genetikai-kulturális koevolúcióként értelmezik az emberi fejlődést. Ennek alapján feltételezhetjük, hogy a kulturális evolúció is az elmékben formálódott, jóllehet a technikai eszközök fizikai megtestesülése is kísérte a folyamatot: a mentális és a nyilvános reprezentációk kommunikációval és utánzással terjednek. A kultúra azokból a reprezentációkból épül, melyek stabilan épülnek be az átadás kauzális láncolatába.

A reprezentációk elemei közül egyesek gyorsabban, változatlanabb módon, míg mások lassabban, és jóval nagyobb átalakulás során terjednek el és épülnek be az interperszonális és a társas kommunikáció mintázataiba. E beépülési folyamattal kapcsolatban érdemes említeni a figuratív mag fogalmát (Moscovici 2003). Moscovici azokat az egymással kapcsolatban álló alapfogalmakat nevezte a szociális reprezentáció figuratív magjának, amely alapfogalmak körül kikristályosodik az adott tárgyról való tudás. Nagyszabású empirikus kísérletében (László 2003) arra volt kíváncsi, hogyan válik a pszichoanalitikus tudományos elmélet a hétköznapi gondolkodás és tudás részévé. 2200 személlyel végzett kérdőíves adatfelvételt,

${ }^{3}$ http://oxforddictionaries.com/definition/meme\#m en gb0510620.004

${ }^{4}$ http://video.miner.hu/v/mero-laszlo-memetika-roviden 2 
mely a párizsi lakosok reprezentatív mintájára terjedt ki. Elemzése kimutatta, hogy a pszichoanalízis már az ötvenes években megjelent a francia társadalom tudatában, jóllehet csak a teória egyes aspektusaira terjedt ki a recepció. A tudattalan, az elfojtás és a komplexus fogalmai a köznapi gondolkodás és beszélgetés részévé lettek. Ez esetben a három fogalom és kapcsolataik alkották azt a figuratív magot, melyhez Moscovici két funkciót is hozzárendelt. Egyfelöl, a figuratív mag a reprezentáció kognitív szerveződésének és a tárgyról való diskurzusnak a centruma. Másfelől, a figuratív mag a gondolkodás és a diskurzus elvont fogalmait konkretizálja - szimbolikusan. Moscovici ennek kapcsán két olyan lépést írt le, mely a szociális reprezentáció folyamatiban alapvetőnek tekinthető. A lehorgonyzás során az ismeretlen, új fogalmak a már ismert kategóriákhoz kapcsolódnak. A tárgyiasitás során pedig konkrét képzetek társulnak az elvont fogalmakhoz. ${ }^{5}$ Mindkét lépés nagymértékben hozzájárul a kultúra különbözöképpen - térbeliséggel, időbeliséggel stb. - jellemezhető elemeinek terjedéséhez.

A társas reprezentációkhoz és azok átadásához kapcsolódik a kommunikátor életvilágának Horányi Özséb (2001b) által kifejtett, a memetikai megközelítés értelmezését támogató kifejezése is: „A kommunikátor életvilága az a sajátos tudáskészlet, amivel az aktuális kommunikációt illetően előzetesen (a priori) rendelkezik, amivel belép az aktuális kommunikációba (...) Az ágens életvilágát (kulturális) mintaként (normaként) is használja mindaddig, amíg az adott helyzet fennáll; ami pedig addig áll fenn, amíg bizonyos előfeltevések fennállnak, így például amíg a társadalmi élet olyan marad, mint amilyen volt (amíg a problémák azonosak, a megoldások is azonosak); amíg bátran támaszkodhat a különböző tekintélyektől megtanult tudásra, akár anélkül is, hogy tudná az adott tudás eredetét és valódi értelmét; amíg elég csak az események általános karakteréröl tudást szerezni ahhoz, hogy kezelni legyen képes magát az eseményeket; amíg a többiek is hasonló recepteket, sémákat követnek." (Horányi 2001b: 62) ${ }^{6}$ Az ágens életvilágának képlékenységét érdemes hangsúlyozni: napjainkra az infokommunikációs technológia fejlődése felgyorsította azon folyamatok hatásait, melyek ennek az életvilágnak az átalakulását befolyásolják.

Ahogy a biológiai reprodukció során sem tökéletes a másolódás, úgy a mémek esetében sem kell annak lennie: éppen a - stabilitást nem fenyegető - adaptív variánsok megőrzése tekinthető fejlődési alapelvnek a biológiai evolúció folyamatában. A mém beépülhet a mentális reprezentációk sorába és az adott személyiség kognitív rendszerébe: ezt a konkrét környezet és az egyén tudatállapota határozza meg. A kognitív rendszerhez való

5 Pléh Csaba szerint Moscovici figuratív magja a durkheimi társadalmi tény fogalmához kapcsolódik: „A durkheimiánus gondolkodásmód valójában a Latour elemezte politikai reprezentáció modern társadalomtudományi lefordításaként is értelmezhető. Durkheim és követői számára az egyéni és a társas reprezentáció között sajátos interakció volt. ...Hasonló gondolatmenetekben, vagyis az egyéni viselkedés távolhatásszerű közvetített determinációjának a magyarázatára újra megjelent a társadalmi reprezentáció elmélete. A hetvenes évektől elsősorban Serge Moscovici (1960, 2002), nálunk pedig László János (1999) munkáiban megint elötérbe került a társadalmi reprezentáció mint értelmező fogalom. Ez lenne az a fogalom, amely hidat teremt a viszonylag egyedi szociálpszichológiai folyamatok - például egy iskolai osztály gondolkodása a rockzenéről - és a társadalomban kultivált gondolatok - például a Rolling Stones jelképes jelenléte - között." (Pléh 2013: 125-126)

${ }^{6}$ Horányi, Ö. (2001): A személyközi kommunikációról. In: I. Béres és Ö. Horányi (szerk.) Társadalmi kommunikáció. Osiris Kiadó, Budapest. http://www.communicatio.hu/konyvek/beres horanyi tarsadalmi kommunikacio/tartalom.htm 
alkalmazkodás nem jelenti okvetlenül új mém keletkezését, noha egy adott mém tartalmának megváltozása új mém keletkezését is eredményezheti. ${ }^{7}$

Sperber (2001) az elmére rövid ideig ható, de adott időszakban nagyobb tömegeket is elérő, járványszerüen terjedő divathullámokról ír. Egy adott mém jelenléte és aktivitása változó lehet: de szelekciójuk minden esetben az elmében és az elmére hatva történik. Sperber sokakhoz hasonlóan (Damasio 1996, Dawkins 1989, Dunbar 1996, Mérő, 2010) ezzel azt az álláspontot teszi magáévá, melynek értelmében a kognitív tényezök egyes elemei hozzátartoznak biológiai létünkhöz. A legfigyelemreméltóbb differencia a dawkinsi és a sperberi felfogás között az, hogy Sperber nem fogadja el az „új replikátor”-feltételezést: szerinte nincs más szempontrendszer, mint a gének szempontjai, tehát a kulturális evolúció változásait sem vezetheti másra vissza, mint az „önző” gének „érdekeire”. A hiedelmek reprezentációjának két típusát különbözteti meg az elmében: az intuitív hiedelmek spontán és tudattalan észlelési és következtetési folyamatok termékei, ezek a hiedelmek konkrétak, és a világ hétköznapi képét adják, a reflektív hiedelmet ugyanakkor valamely megbízható tekintélybe vetett bizalom hitelesíti.

A mémek szempontjából az ilyen típusú különválasztás másképpen értelmezhető: spontán hiedelmeknek számíthatnak a kulturálisan mélyebben beágyazott mémek, az erkölcs, a jóra való törekvés, a csoport elfogadása, a reflektívek pedig az egyénben később lerakódó, akár az előzőeknek ellentmondó, esetleg azokat felülíró, a habitust alkotó mémek. ${ }^{8}$ Dawkinsnál a gondolatok replikatív rendszert alkotnak, mint a gének, Sperber eszmefuttatásában pedig a gondolatok szervezetröl-szervezetre vírusokként terjednek.

Visszatérve a genetikai analógiához: életképes utód születéséhez szükséges egy másik génállománnyal rendelkező egyed, akinek génstruktúrája jól azonosítható, a külső jegyekből visszakövetkeztethetö. Befolyásolhatja ugyan a biológiai öröklődést a spontán mutáció, de nem feltétlenül fog a következő generációban megjelenni. A mémek esetében igen ritka a tökéletes másolódás, ${ }^{9}$ jóllehet a napjainkban gyakran internetes mémekként jellemzett tartalmak vizuális és szöveges formában is igen gyakran változatlanul terjednek. A dawkinsi a XXI. század második évtizedének elején már-már elmondhatjuk: klasszikus - értelemben vett memetikai megközelítés szerint a mémek egyénre jellemző módon épülnek be a másik személy tudatába, miközben megmarad a mém tartalmi magva, jóllehet a mémek, a génektől eltérően, meghatározott mértékig egymással is tudnak elegyedni. Mivel az átadó továbbra is rendelkezik a mémmel, a transzmisszió replikációként értelmezhető: a mémről másolat készül a másik személy memóriájának struktúrájába integrálódva, mém-hordozóvá téve őt. Ez a replikátor önreprodukciója, melynek során a mém az egyének egyre nagyobb csoportját teszi hordozóvá. Dawkins (2005) azokat a külső megnyilvánulásokat tartja a mémek fenotípusainak, melyeket egy vagy több másik egyén utánozni tud, s melyek az elmék közötti terjedésre képesek. Kérdés, hogy a mémeknek van-e az agyban fizikai struktúrájuk. E pillanatban még nem tudjuk a választ, noha mára bizonyítottnak tekintjük Damasio (1996)

${ }^{7}$ „Darwin elméletének mémje ennélfogva elképzelésének az a lényegi alapja, amelyben mindazok az agyak egyetértenek, akik értik az elméletet. Az abban levő különbségek tehát, ahogy az egyes emberek az elméletet képviselik, definíció szerint nem részei a mémnek." (Dawkins 2005: 182)

${ }^{8}$ A megismeréstudomány lehetséges metszeteiben mind Sperber epidemiológiai felfogását, mind a dawkinsi memetikát a külső horizontális felfogás fogalmával illeti Pléh Csaba, szociális szemantikának tekintve azt. Pléh szerint az alapkérdés: hogyan viszonyulnak mások reprezentációihoz az egyedi megismerő rendszerek (személyek) reprezentációi. „Az egyik kérdés szerkezeti: mennyire hasonlítanak egymáshoz a gondolatok. A másik kérdés genetikus: hogyan jön létre a reprezentációs rendszerek összehangolása?” (Pléh 2013: 150)

9 Atran, S. (2001) A cheater detection module? Evolution and Cognition, Vol. 7, pp. 183-193. 
szomatikus marker elméletét: az adott ingerre aktivizálódó szomatikus markerek olyan neuron-összekapcsolódások, amelyek érzékelési, érzelmi és kognitív elemekkel is bírnak. Például, ha valaki az utcán észrevesz egy számára valamilyen okból releváns márkajelzést: ez a vizuális inger aktivizálja azokat az elemeket, melyek az egyénhez eljutottak az adott cég kommunikációjából. ${ }^{10}$

A mémről szóló gondolat sokszor nyelvi alakváltáson átesve másolódik (Pléh 2000). Az adott személy gondolatstruktúrájába bekerülő mém akkor életképes, ha adaptálódik az ott jelenlévő mém-ökoszisztémához, az illetőnek az adott közegben jellemezhető identitásától függően, vagyis az intra- és interperszonális kommunikációban az adott narratívához illeszkedve transzformálódik az adott mém: Bruner (1996) szerint az emlékeket mindig annak függvényében teremtjük újra, hogy milyen információk állnak rendelkezésünkre.

Pléh Csaba a memetikát a tanult, illetve az öröklött rendszerek problémájának, új megfogalmazásának tekinti: „maguk a reprezentációk két materiális formában léteznek: mint mintázatok az egyéni idegrendszerben, s mint publikus, fizikailag megvalósult jelek. Emberközi tényezők, például a hatalom, a szeretet, a véleményirányítók befolyásolási paraméterei határozzák meg, hogy a reprezentációk melyik irányba terjednek, és mely reprezentációk válnak népszerüvé. Az emberi elme ugyanúgy érzékeny a kulturális reprezentációkra, ahogyan az emberi szervezet a betegségekre." (Pléh 2000: 175).

A tudatot magyarázó írása alapján Dennett (1991) szerint a mémek olyan ideatöredékek, melyek önmaguk megsokszorozására törekednek, ám legnagyobb hányaduk elöbbutóbb eltünik: „Az emberi agyak nem hasonlítanak egymásra: különböznek méreteikben, formájukban és számtalan részletükben, melyektől hatékonyságuk függ. De eme hatékonyság a mikrostrukturális különbségeken múlik leginkább (melyek máig megfejthetetlenek a neurobiológia számára), így alkalmas lakhelyekké válnak a mémek számára. A mémek erősítik egymás replikációs esélyét: az oktatás mémje például javítja a mém-implantáció körülményeit. Ha viszont igaz az állítás, hogy az emberi elme maga is nagymértékben a mémek kreációja, nem tartható a kezdeti víziónk polaritása: nem lehet harc a mémek és mi közöttünk, hiszen korábbi mémek játszottak igen nagy szerepet annak meghatározásában, hogy kik és mik vagyunk." (Dennett 1998: 367)

A mémek nagy része tehát eltünik, kipusztul: ám amelyik fennmarad, annak pozíciója megerősödik, s ilyenképpen már domináns mémként határozza meg, illetve befolyásolja változó mértékben - a gondolkodást: Dennett ezeket nevezi új replikátoroknak. „Nem a lockei és hume-i értelemben vett „egyszerü ideák” (mint a piros, kerek, a meleg és a hideg ideája), hanem azok a komplex ötletek, melyek megjegyezhetö egységekké képesek önmagukat alakítani." (Dennett 1998: 360) Dennett szerint kulturális entitások vagyunk, s nem kulturális követők, ennek alapján a mémeket kulturális tárgyaknak tekinti: a mémek szerinte parazitaként is beilleszkedhetnek az elmébe, vagyis a végső haszon a mémé, s nem pedig a mémet hordozó ágensé. Meghatározása alapján a mém egy ,attitűddel rendelkező információcsomag" (Dennett 2002b: 8). E mémnek van egy megkülönböztető hatású

${ }^{10}$ Itt érdemes megemlíteni az Edelman által neurális darwinizmusnak nevezett elméletet is. Eszerint „egyrészt a megismerési mintázatok kibontakozásának fejlődési kulcsa az idegrendszer egyedfejlődése, másrészt ebben az egyedfejlődésben tulajdonképpen különböző neurális hálózati minták közötti versengés és szelekció megy végbe: az idegrendszer egyedfejlödése különböző lehetséges fogalmak (koncepciók) hálózati előképeit hozza létre. A perceptuális tanulás elveinek megfelelően a szelekció azután úgy érvényesülne, hogy amelyikkel ezek közül ténylegesen találkozunk, az mintegy felerősítődik, míg a többi degenerálódik. A fogalmak előképei az idegrendszer hálózatszerveződésében bontakoznának ki, s a tanulás csak az ezek közötti szelekciót jelentené." (Pléh 2013: 258) 
fenotípusa, s az elmébe kerülve fenotípus-változást eredményez, ezáltal az adott kultúra lenyomatát is megteremti. Dennett analógiája erős negatív jelentéseket sugall: a mémeket - a géneknél gyorsabban kihaló, gyorsabb lefolyású evolúcióval bíró - élősködőknek látja, akik az analógiában gazdatestnek tekintett emberrel szimbiotikus viszonyt alakítanak ki (Dennett, 1998).

Blackmore a dennett-i elméletből kiindulva már az én-mémről, a self-plex-ről beszél (Blackmore 2001: 219). A blackmore-i self-plex az egyén világot értelmező folyamatos narrációjának az alanya. Amennyiben elfogadjuk az én-mém feltételezést, úgy a pszichológiai jellemzők fontosak maradnak, de csak részben: ugyanis az én-mém pszichéként szintén mémekből épül fel, tehát az új mémek befogadása, de elutasítása is az egyén mémkészletének függvénye. Fontos megjegyezni: a self, mint különösen gazdag, ismereti rendszer a memetikai megközelítésektöl függetlenül is megjelent a társadalomtudományokban - például: (Banaji 2003) -, ám azzal a megszorítással, hogy egyelőre a jövő feladatának tekinthetjük e szerveződés felvázolásának munkáját.

Nem minden mém, ami az emberek „fejében van” - figyelmeztetnek a memetikusok. Blackmore három forrást különböztet meg, melyek közül csak az imitáció vezet mémátadáshoz. Az imitáció mellett beszél a fertözésről, amelyre egyik legjobb példa a nevetés, vagy az ásítás, valamint a szociális tanulásról, amely egy meglévő magatartásforma új környezetben való alkalmazását segítheti elő (mint amilyen például az angliai cinkék, akik a kutatások szerint eltanulták egymástól járványszerüen a tejesüveg tetejének csőrrel való megnyitását).

Distin (2005) nemcsak Dennett elméletét bírálja (s mellette számos más memetikai megközelítést is kritikával illet), hanem a társas tényezőt is beemeli a memetikai értelmezésekbe: $A z$ önzö mém címü könyvében a vírusterjedési elmélet ellenében érvel, túlságosan erős analógiának nevezve azt, hiszen a mémek képtelenek másolási mechanizmusok létrehozására. Distin kiemelt szerepet tulajdonít a nyelvnek, a mémek DNSeként értelmezi azt: ${ }^{11}$ álláspontja szerint az aktuális beszélt nyelvet alkotva a nyelvrendszer egyes elemei, a szavak is lehetnek mémek. Továbbá abban sem ért egyet Dennett koncepciójával, hogy a mémek hordozó nélkül is tudnak öröklödni: a mémeket a másolódást elősegítő helyzetekért felelős szociális folyamatok során átadódó, nagyobb információs egységként definiálja. Mivel a mentális tartalmakat tekinti a kulturális evolúció alapjainak,

${ }^{11}$ A nyelv és a DNS kapcsolatáról egyre több multidiszciplináris eredmény jelenik meg napjainkban is, például Towards practical, high-capacity, low-maintenance information storage in synthesized DNA. Nick Goldman, Paul Bertone, Siyuan Chen, Christophe Dessimoz, Emily M. LeProust, Botond Sipos és Ewan Birney. Nature Vol. 494, pp. 77-80. (2013 február 7.): "Digital production, transmission and storage have revolutionized how we access and use information but have also made archiving an increasingly complex task that requires active, continuing maintenance of digital media. This challenge has focused some interest on DNA as an attractive target for information storage because of its capacity for high-density information encoding, longevity under easily achieved conditions and proven track record as an information bearer. Previous DNA-based information storage approaches have encoded only trivial amounts of information or were not amenable to scaling-up, and used no robust error-correction and lacked examination of their costefficiency for large-scale information archival. Here we describe a scalable method that can reliably store more information than has been handled before... Theoretical analysis indicates that our DNAbased storage scheme could be scaled far beyond current global information volumes and offers a realistic technology for large-scale, long-term and infrequently accessed digital archiving. In fact, current trends in technological advances are reducing DNA synthesis costs at a pace that should make our scheme cost-effective for sub-50-year archiving within a decade." 
ezért azokat látja mémként értelmezhetőnek: a mind több ember elméjében megjelenő mémek egy idö után az adott közösség kulturális modelljévé válnak.

A memetika elmélete azóta vitatott, amióta megszületett. ${ }^{12}$ Sok ellenteória fontos érveket sorakoztat: keveset tudunk a mémekröl, a méretükröl, a kódolásukról, a terjedésük pontos menetéröl, pszichés beágyazottságukról, stb. Az elmélet jövőjéről Mérő ezt írja: „Senki sem vitatja, hogy a memetika valóban létező jelenségeket vizsgál. A mémelmélet megtanít minket együtt élni azzal a gondolattal, hogy nemcsak testileg, hanem lelkileg is önző replikátorok termékei vagyunk. Az előbbit a Darwin utáni másfél évszázad alatt nagyjából tudomásul vettük, és ez után talán már az utóbbi sem fog különösebb megrázkódtatást okozni. Ha a memetika jelenlegi formája egy tudományos zsákutcának bizonyul, akkor ugyanezeket a tanulságokat egy másik, érvényesebb elmélet keretében vesszük majd tudomásul. Ez esetben a memetika úgy vonul majd be a tudománytörténetbe a flogiszton- és az éterelmélet mellé, mint egy téves elmélet, amely tévedéseivel fontos jelenségekre hívta fel a figyelmet, és alapvető szemléleti változásokat készített elö." (Mérö 2004a) A párhuzam a kommunikációelmélet területén is megjelenik: „Az olvasóban joggal támadhatnak kételyek: egyrészt azt állítom, hogy nincs kommunikáció, másrészt pedig azt fejtegetem, hogy ezt a gyüjteményt miféle elgondolások alapján állítottam össze a kommunikációról szóló tengernyi irodalomból. S ez az ellentmondás - ahogyan én látom - mélyebb annál, semhogy látszólagosnak volna minősíthető. Tudománytörténeti közhely a flogisztonelmélet. Elég sokat vitatkoztak, elmélkedtek róla, nem kevés a könyvek száma sem - ma mégis úgy ítéljük meg, hogy flogiszton pedig nincs (...) a példa ugyanis azért jó, mert segít megkülönböztetni a tudományos értelemben vett zsákutcát az egyszerü szamárságtól. A flogisztonelmélet ugyanis nem szamárság, minthogy valódi, ma is érvényes kérdésre próbált válaszolni. Igaz, a válasz, mai ismereteink fényénél, rossz volt, zsákutcába tévedt a tudomány vele.” (Horányi 2003: 11)

A fentiek alapján mémeknek azokat a mintázatokat tekintjük, amelyek terjednek: a mém a kultúra legkisebb, terjedésre képes egysége. A mémek fajtái között Rushkoff (1995) három általános csoportot különböztet meg: az önképződö, azaz természetes úton létrejövő mémeket, az átvett vagy felerősitett mémeket, amelyeket létrejötte után a mémek terjesztésével foglalkozó memetikusok tervszerüen használnak saját céljaikra, illetve a tervezett mémeket, amelyek megteremtése is tervek végrehajtását szolgálja. Csányi Vilmos etológus (Csányi 1979: 97) az ideákat (reprezentációkat) „,populációszintű önálló fizikai entitások”-nak tartja. ${ }^{13}$ A memetikus továbbmegy: a mémeket az egyének szintjén is önálló entitásnak, mint ilyet pedig replikátoroknak tartja.

A mémek tehát gondolatok legkisebb, önmagukban is értelmes részei, amelyek föleg utánzás révén terjednek az egyik emberi agyból a másikba. Akárcsak a gén, mém is egyfajta generátor: a mém "gondolat-lényeket" generál. A mém természeténél fogva replikátor, ahogyan a gén is az. A mém-komplexum lényegében ugyanaz, mint amit a kognitív pszichológiában kognitív sémának neveznek: életképes gondolati egység, amely a természetes szelekció tárgya, ahogy a biológiában az egyes lények. ${ }^{14}$

${ }^{12}$ A vita hazai és nemzetközi viszonylatban is érzékelhető polarizálódása álláspontom szerint megtermékenyítően és inspiráló módon hat a szemlélet érlelődésére és specifikálódására.

${ }^{13} \mathrm{Ha}$ párhuzamot szándékoznánk vonni Csányi munkássága és a memetika teoretikusainak munkássága között, akkor a Csányi által (1999) a csoportorganizmusnak tulajdonított ideakonstrukciók feltehetöleg a blackmore-i mémplexnek lennének megfeleltethetök.

${ }^{14}$ Mind a biológiában, mind a pszichológiában, sőt a filozófiában is nagy múltra tekint vissza az elmélet, miszerint egy-egy ember fején belül szintén szelekciós rendszerek lehetnek. A szelekciós rendszerek fogalmát a korábban már említett Edelman vezette be az immunológiába, szelekciós elméletben értelmezve az immunrendszer müködését. Pléh Csaba ennek kapcsán a következö, 
Mindazonáltal, csakis azok az egységek tekinthetők mémeknek, amelyek utánzás útján terjednek és amelyek rekombinálódhatnak. Tipikusan nem mémek általában az alapvető pszichológiai működések (alapérzelmek, attitüdök, ösztönök, énvédő mechanizmusok, stb.). ${ }^{15}$ Ezek ugyanúgy eleve adott külső mechanizmusok a mémek müködéséhez, mint ahogyan a gének müködéséhez is számos eleve adott fizikai és kémiai mechanizmus szükséges, amelyek nincsenek külön belekódolva a DNS-be, például a politikai, társadalmi és a gazdasági tényezök stb.

E cikkben nem kap helyet olyan újfajta megközelítések tárgyalása, mint az epigenetika, kibontakozás közbeni gén aktiválás és ennek potenciális hatása a mémek terjedésére. Mindazonáltal tekintve hogy a memetikai analógia a génre fókuszál és „mém-sejtet” (még) nem ismer, ezért a sejt-membránra fókuszáló epigenetikai megközelítés talán limitált a mémek esetén. Figyelmünket azonban nem kerülte el, hogy az utóbbi időben erőssé vált ez a szemlélet a genetikában és további kutatási tervek egyik különösen érdekes iránya lehet a memetika és az epigenetika kapcsolatának és egymásra hatásának feltárása.

Az 1. ábra (Mérő 2004b, 2007) Mérő azon gondolatmenetét illusztrálja, melyben a gén/mém analógiából kiindulva az életjelenségeket produkáló élőlényeket gének generálják, $\mathrm{s}$ a mémek által létrehozott kognitív sémák pedig a gondolatokat.

\section{1. ábra}

Teljes logikai párhuzam az élet különféle formái között

\begin{tabular}{|l|c|c|c|}
\hline & Biológia & Pszichológia & Gazdaság \\
\hline A replikátor & gén & mém & tőke \\
\hline A lények & élőlények & $\begin{array}{c}\text { kognitív sémák } \\
\text { mémlények }\end{array}$ & vállalatok \\
\hline A produkció & életjelenségek & gondolatok & termékek \\
\hline
\end{tabular}

Időről-időre kiválogatódnak az illeszkedésre kevéssé vagy egyáltalán nem képes tudatelemek, és újabbak kerülnek be - ilyeténképpen alkot müködő rendszert a mémek adaptív dinamikával is jellemezhető csoportja. A mémek rendszerének változása az önálló mémlények viszonyára is hat: ez a folyamat maga után vonja a gondolatok átalakulását is.

platonisztikus gondolatmenetet fejtegeti: „Mi mind úgy jövünk a világra, hogy milliós nagyságrendü különböző lehetséges külső ártó hatásra rendelkezünk immunreakciókkal. Olyan lenne ez, mint egy platonisztikus immunrendszer. De akkor haladjunk tovább a platóni analógián! Platón szerint a fogalmak bennünk szunnyadnak, és szükség van valamilyen tapasztalatra, hogy aktiváljuk öket. Ugyan benne van a rabszolga fejében is a háromszög fogalma, de ahhoz, hogy aktiválódjék, mutogatni kell neki háromszögeket. Az immunrendszernél ugyanez van: az immuntanulás során az antitest-repertoárból kiválasztás megy végbe. Fel fognak erősödni azok, amelyekkel találkozunk, és szunnyadva maradnak azok, amelyekkel nem találkozunk.” (Pléh 2013: 258)

${ }^{15}$ Idetartoznak azok a magasabb rendü kognitív mechanizmusok is, amelyek agykérgi szabályozás alatt állnak, és bár az emberi evolúciós környezetben alakultak ki, azonban az aktuális körülmények szolgáltatják mindenkori tartalmukat. A gyermekkori családi tapasztalatok feldolgozását is veleszületett tanulási és bevésődési folyamatok irányítják. (Bereczkei 2009: 258) 
Az emberiség számára roppant lényeges az általunk mémhalmazokként definiált közös tudatelem-csoportok megléte: az emberi csoportok a világot közös konstrukciókon és közös gondolati konstrukciókon keresztül értelmezik. ${ }^{16} \mathrm{Az}$ állatvilágból való sikeres felemelkedésünk legfontosabb oka az, hogy nagyobb közösségeket tudtunk létrehozni, mint a primáták, melyek közösségei jóval korlátozottabb létszámúak. E nagyobb közösségeinkben az imitáció segítségével már az emberré válás kezdetétől viselkedéseket, később gondolatokat is tudtunk cserélni, majd az elmékben hasonló gondolati és tudattartalmakat kialakítani.

Az emberi közösségek létrejöttében kulcsszerepe volt tehát annak, hogy az emberek közös konstrukciókat, közös hiedelmeket tudtak létrehozni, s közös akciókat tudtak végrehajtani, akár 120-150 fös közösségekben is (Dunbar 1996, 2007): mindennek az alapja, hogy a közösség tudott magáról és tudott egymásról. Ezzel kapcsolatos tézisei ma már interdiszciplinárisan, a statisztikus fizikai művelői és a pszichológusok között is elfogadottnak számítanak $^{17}$.

A közösség vagy a csoport fogalmának komplexitása széles szociológiai és szociálpszichológiai irányokat nyithatna: a memetikai megközelítése jellegéből fakadóan Horányi Özséb közösségértelmezését veszem alapul. Horányinál az ágensek (kommunikációs) közösségeket (communio) alkothatnak, ahol a közösségeket, akármilyenek is legyenek, egyrészt a problémamegoldásra vonatkozó közös felkészültség teszi (közös, mert az adott felkészültség a közösség minden tagja számára egyaránt elérhető) beleértve a problémamegoldás sikeressége érdekében történő kooperációra vagy kompetícióra való közös felkészültséget; másrészt pedig a kooperációra vagy a kompetícióra való igény teszi. Voltaképpen más közösségről, mint kommunikációsról nem lehet beszélni (a társadalom, mint kívülről elhatárolt közösségek konglomerátuma tekinthető) annak okán, hogy a problémamegoldáshoz szükséges felkészültség különböző típusai (végső soron az ágens típusai) és sajátos megvalósulásai (az ágensek egyéni felkészültségei) a közösség-képző tényezők, amelyek mentén a típusonként különbözö közösségek létre tudnak jönni, vagyis tagolttá válhat a közösség. Egy adott ágens szempontjából pedig ez azt is jelenti, hogy egyszerre több különbözö közösség tagja (is) lehet. (Béres és Horányi 2001) Ez a közösségértelmezés lehetővé teszi annak elfogadását is, hogy a memetikailag hasonlónak mondható csoportok átfedést hozzanak létre: a társadalom változásai ugyanis gyorsan rajzolják át a terjedés határait. A közös tudattartalmakra épülö közösségek adják tehát az emberiség kiemelkedésének, fejlődésének a zálogát: e folyamat alapja, hogy mit gondolunk társainkról, mi van a fejünkben a közösségröl, illetve egymásról, s melyek azok a közös tudattartalmak, amelyek meghatároznak egy adott közösséget. A csoportszelekciós elmélet (Síklaki 2008, Smith és Mackie 2001) a memetikai megközelítésre is hat: hiszen az, hogy kivel, kikkel vannak közös mémjeim, manapság a csoportba tartozás fontos mutatójának is felfogható. Amit egy adott egyén gondol például az abortusz tiltásáról vagy engedélyezéséről, a házasság intézményéről vagy a népnemzet helyzetéről, meghatározó: feltételezésem szerint

${ }^{16}$ Csányi Vilmos az evolúciós folyamat végén megjelent új biológiai tulajdonságokat az egyén és a csoport közötti viszony szempontjából vizsgálva öt döntő változást értékel ezzel kapcsolatban: a közös eszmék és az emberi moralitás megjelenését, a közös akciók és a kooperáció kialakulását ezen eszmék által meghatározott keretben, a közös konstrukció kialakulását (az eszmék és az akciók lokális, egyedi, érzelmi és racionális analízis alatt állnak, s ennek eredményei visszacsatolódnak a magasabb szintre), valamint a hüség, s végül a transzformáció létrejöttét (a csoportot alkotó emberekből egy új entitás, a magasan szervezett önálló csoportorganizmus alakul ki). Csányi, V. (2000) Humánetológia. Magyar Tudomány Vol. 4, pp. 397-416.

http://epa.oszk.hu/00700/00775/00017/397-416.html (2010-11-17)

${ }^{17}$ Dunbar, R.I.M. és munkatársai (2007) Evolution in the Social Brain. Science Vol. 317, pp. 1344. 
az a mém, mely jobban terjed a többinél, valójában jobban illeszkedik ahhoz a mémkörnyezethez, amelyben terjedni akar - más szavakkal: jobban beletalált egy mintázatba.

Ha a fentiek alapján elfogadjuk, hogy léteznek mémek és a mémek által megszülető, illetve terjesztett gondolatok, akkor ennek alapján az evolúciós megközelítésböl következik az is, hogy a mémek terjedni akarnak a gondolatokon és a kommunikáció teljes spektrumán (intra- és interperszonális, csoporton belüli, valamint csoportközi és tömegkommunikáció, social media etc.) keresztül: a kérdés tehát az, hogy a mémek hogyan terjedhetnek a legjobban. Több oka is lehet az egyénnek, amikor az utánzás stratégiáját választja: Laland (2004) ebből hármat említ. Egyfelől, ha az adott egyén mentális készletében nincs eredményes választ adó minta, érdemes egy másik, sikeresnek talált egyén viselkedését másolni. Másfelől, ha az egyén felméri a tanulás pszichológiai költségeit, és a becslés alapján az utánzást találja kifizetődőbbnek. Végül, ha a szituatív környezet aspektusainak értékelése nem ad elegendő biztonságot.

A terjedésben nagy szerepet játszik a másolási pontosság, amely a digitális technológia fejlődésével nagyban megnőtt. Az infokommunikációs technológia segítségével a másolás és így a terjedés sebessége is nö: így a pontos másolatok könnyebben és gyorsabban juttathatóak el a világ bármely, behálózott pontjára. Az új technológiák hálózati jellege a terjedést a hálózati dimenzióban is felgyorsítja: egyszerüsödik a hozzáférés a mémekhez a World Wide Weben. A linkek segítségével a mémek terjedése visszahathat a csatlakozó mémek terjesztésére, a népszerü mémek pedig visszacsatoló módon kiemelkedhetnek a hálózati hatások következtében. A legnépszerübb internetes kereső, a Google keresési módszere önmagában hordozza a memetikai visszacsatolást: minél több hivatkozása van egy dokumentumnak, egy hírnek, egy képnek a weben, annál többen fogják elolvasni, és annál több új hivatkozást tud szerezni, mert annál magasabbra kerül ennek hatására a találatok között. És minél inkább azok hivatkozzák, akik már eleve magasan vannak a találatok között, annál magasabbra kerül az adott tartalom maga is. A változás következő rétege az internetes reprezentációk hálózatának kialakulása: ez egyszerre jelent társadalmi hálózati modellt és önálló jogon vizsgálandó hálózatot is (Csányi és Szendrői 2003).

Nagyságrendbeli változást jelent, hogy a statisztikus fizikusok napjainkban már akkora mennyiségü elemszámot tudnak vizsgálni, mely korábban elképzelhetetlen volt. A mai értelemben vett hálózatkutatás története Stanley Milgramtől (Milgram 1967) és Mark Granowettertől (Granowetter 1973) a Watts és Strogatz pároson (Watts és Strogats 1998) keresztül Barabási és szerzőtársai munkásságáig (Barabási és Albert 2001) halad, akik döntő lépést tettek a Granowetter által azonosított úgynevezett weak linkek, azaz gyenge kapcsolatok által meghatározott kicsi világok (small world) hálózati modellezésében. A társas hálózatok esetében egy csoport tagjai lesznek a hálózat pontjai, melyeket élek kötnek össze. Ám minden kapcsolat számos változóval írható le, következésképpen a statisztikus fizika absztrakt hálózat-ábrázolásai drámaian egyszerüsítenek. A társadalomtudomány és a természettudomány kooperációjából megszülető általános elméleti keret, a hálózati gondolkodás viszont olyan modelleket szolgáltathat, melyek támogatják a szociálpszichológiai és szociológiai elemzéseket, választ adva arra, hogy a társas tudás (László 1999) miképpen hat a motívumokra, s miképpen hatnak vissza a struktúrára az (egymásra is ható) motívumok. A hálózatelmélet segítségével modellezni tudjuk egy társadalmi hálózat kialakulását és az abban zajló átadási folyamatokat, következtetni tudunk a hálózat növekedésének ütemére és következtetéseket tehetünk a terjedés megfigyelése alapján a hálózat tulajdonságaira is. Az emberiség társadalmi hálózata több vonatkozásban, például a szexuális szokások tekintetében is scale-free (skálafüggetlen) eloszlást mutat (Liljeros, Edling és Amaral 2003) Az emberiség mémjeinek terjedését is vizsgálhatjuk az epidemiológiából származó modellek segítségével, ahol, hasonlóan a vírusokhoz, bizonyos mémek fertőzőbbek másoknál, tehát jobban terjednek majd a hálózatban. 
A mémek terjedésének vizsgálatakor a hálózatok általános adottságainak, valamint egyedi tulajdonságainak felmérése további segítséget nyújthat. A központi kontroll hiánya, az egyedek autonóm állapota és magas összekötöttsége, illetve a kapcsolatok hálózatában a hatások nem lineáris, hanem hálószerü volta mind elősegíti a gyorsabb terjedést. Hasonlóan a világháló feltérképezett topológiájához (Broder 2000), a networkök topológiájának, a közösségek egymáshoz képest való elhelyezkedésének megértése kulcs a mém-terjedés kérdésében is.

A memetikában általánosságban bárki lehet host, azaz mémgazda, aki birtokában van annak a potenciális kapacitásnak, hogy felismerje a mémeket és késztetve legyen azok terjesztésére. Gladwell szerint (Gladwell 2000) a diffúziókban a kevesek szabálya érvényesül: nem feltétlenül a sokaság akciója a döntő, hanem a kevés különleges, különösen behálózott egyén választása, mint a kovász az erjedésben. Gladwell három olyan szereplőt azonosít a hálózatokban, akiknek a tevékenysége nélkül a terjedés nem indulna meg. Az összekötő (connector): szenvedélyes gyüjtője a weak linkeknek, a gyenge kapcsolatoknak; a gyüjtö (maven): aki önkéntesen gyüjti és terjeszti az információt; s végül az ügynök (salesman): a terjesztésben releváns képességeit egy adott ügy érdekében embertársai meggyőzésének szolgálatába állítja.

Gladwell hús-vér figuráit a hálózati tudomány hub-oknak, központoknak nevezi. A Barabási és munkatársai által jellemzett skálafüggetlen hálózatokban több ilyen $h u b$, központ is előfordul, melyek gyökeresen megváltoztatják a hálózat gráfját és ezáltal a benne terjedő információ terjedési természetét is. A hub-ok karakterisztikájának előzményeit közvetlenül Burt munkásságában (Burt 1982) lelhetjük fel, ma már igen sokféle meghatározás és jellemzés található társadalmi szerepeikkel kapcsolatban.

A hálózatok támadhatóságának tekintetében a random és a skálafüggetlen hálózat különbözik egymástól. Ennek oka, hogy az emberek hálózata asszortatív: a nagy node-ok, a helyi központok „összetartanak”, ismerik egymást, míg az internet disszortatív, a nagyobb központok „széttartanak”, egymástól való távolságuk nagy. Ezért támadható az internet például egy DOS-támadással, és ugyanezért nehezen állíthatóak meg a vírusok az emberi hálózatokban (Szendrői és Csányi 2003). Eszerint, ha a terjedési folyamatban az egyed $n$ lépésben (vagy $n$ idő után) megfertőződik, akkor $n+1$ lépésben minden szomszédja is automatikusan megfertőződik bizonyos valószínűséggel. ${ }^{18}$

Az eddigiek alapján feltételezhetjük, hogy egy adott mém terjedése két ok következtében lassulhat le és/vagy állhat meg: vagy a társadalmi hálózat topológiája korlátozza a terjedést, vagy a mém esett a festingeri (Festinger 2000) kognitív disszonancia redukció áldozatául. Komplex és strukturált mémkészletté való összeállásuk is annak jegyében képzelhető el, hogy egymást kölcsönösen támogatják, amikor közös terjedési valószínüségük meghaladja a külön-külön elképzelhetőt. Ilyen komplex mémkészletek lehetnek a vallási és politikai dogmák, társadalmi mozgalmak, müvészeti stílusok, tradíciók és szokások, stb.

A mémek külső környezetét az emberi tudatban az érzelmi oldal jelenti. Az alapérzelmek, mint említettem, nem mémek: kapcsolódhatnak hozzájuk mémek, melyek kifejezőivé válhatnak az alapérzelmeknek - a mémek ,,adhatnak új szavakat” az embereknek, hogy az alapérzelmeket leírják, megjelenítsék az adott pillanatnak megfelelően. Kivétel a szeretet, mely nem alapérzelem, hanem akciókban megnyilvánuló összetett érzelem (Mérő 2010). Az akciók létéből tudhatjuk, hogy két ember között fennáll a szeretet: ez memetikai

\footnotetext{
${ }^{18}$ Napjainkban mind a társadalomtudomány, mind a természettudomány használja a terjedés fogalomköréhez kapcsolható nevezéktanban a vírus, a disszemináció, a diffúzió, a fertőzés és más kifejezéseket, gyakran interdiszciplináris konszenzus nélkül.
} 
módon, utánzással terjed: egymást szerető emberek viselkedését tudják utánozni mások. Az első példaadó erre Jézus volt. Előtte is létezett már kifejezés a szeretetre, a görög agape szó például, ám igazán elterjedtté Jézus tette a szeretetet, mely utánzással terjed a világban. ${ }^{19}$

Egy érzelem támogathat egy adott mémet: ha valaki az adott mémet mondta vagy hallotta, és a helyzethez pozitív érzelmek társultak, például gazdasági környezetben pénzt kapott - az egyént sikeresebbé tette az adott mémmel való kapcsolata. Példával illusztrálva: miközben Magyarországon fennáll egy erős kapitalizmusellenesség, ennek ellenére az angol nyelv és az amerikai kifejezések - az angolszász mémek - közkedveltek. Ha valaki angolul nevezi el a cégét, máig hatással van arra, hogyan értékelik az adott céget.

Egyetlen mém sem létezhet légüres térben: a környezet alapvetően meghatározó, minden mémnek megvan a maga helye és ideje. Sok üzleti vállalkozásról hallhatunk, mely csak azért lesz sikertelen vagy sikeres, mert időzítése rossz vagy éppen jó. Több olyan cégröl is tudunk, akik idő előtt jelentek meg a piacon olyan termékekkel és szolgáltatásokkal, melyek az aktuális mémkészletnek nem feleltek meg, és néhány év múlva egy másik piaci szereplö ugyanazzal a szolgáltatással vagy termékkel nagy sikert aratott - ilyen például a Starbucks. A kávéházat 1971-ben alapította Seattle-ben egy történész, egy irodalmár és egy író, és hosszú évek - és a Brooklyn legszegényebb negyedéből származó Howard Schultz megszállottsága - kellett ahhoz, hogy az olaszos kávézást körülvevő hangulat globális mémmé váljon. ${ }^{20} \mathrm{~A}$ kávézás és a beszélgetés közti viszony olyannyira közismert, hogy ezen a ponton érdemes felidézni Labov és Fanshel Terápiás beszéd címü tanulmányának (Síklaki 2008) vezérgondolatát: „...a beszélgetés nem megnyilatkozások lánca, hanem inkább értelmezések és reakciók hálójával egybekapcsolt megnyilatkozás és cselekvésmátrix." Labov ugyanis, Goffmanból kiindulva, nem nyelvi, hanem emberek közötti interakciós formának tekinti a beszélgetést.

Az egyes elmékben megszilárduló gondolati-fogalmi struktúrák és kapcsolatok alapvetően nehezen változtathatók meg (Banaji 2003 és Babbie 2003). Antropomorfizálva, megszemélyesítve az elmékben lévő gondolatokat, elmondhatjuk velük kapcsolatban, hogy nem nagyon szeretnének új, további gondolatokat befogadni. Beérik azzal, hiszen ez optimális a számukra, hogyha uralva az elmét, meghatározhatják egy adott témában, egy adott környezetben a gondolkodást. Így aztán, amikor új mémek akarnak beépülni, ezeknek oly módon kell ezt megtenni, hogy konformnak tünjenek a már létező mémekkel. Rushkoff (1995) héjmag-teóriája azt írja le, hogy bizonyos gondolatok álcázzák magukat ahhoz, hogy bejussanak a mémtérbe, de valójában a mélyükben, a magvukban egy másik gondolat a tulajdonképpeni üzenet maga (Rushkoff 1995).

Egy másik megközelítés: Sperber (Síklaki 2008) szerint a relevancia elvével jól magyarázható a megértés anélkül, hogy nehézséget jelentene a kölcsönös tudás jellege.

19 „Amikor Jézus a szeretetről beszél, azt a mai pszichológia felől nézve tekinthetjük úgy, hogy ezzel a keresztény ember szelfjét definiálja...Minden vallásban fontos szerepet játszik a szeretet fogalma, de Jézus volt az, aki az emberi lét alapfogalmává, s ezzel végérvényesen tisztán emberi érzelemmé tette... Talán épp azért volt szükség Jézusra, mert a szeretet, ez az alapvető fontosságú érzelem nem alapérzelem, semmilyen biológiai módon nincs belénk programozva, és így csakis kognitív (azaz gondolkodás útján létrejövö) érzelem tud lenni - ez alól talán csak az anyai szeretet kivétel. A szeretetet tanulni kell, csak úgy magától általában nem jön létre bennünk, mint ahogy a tanult tehetetlenség sem....Igazából semmi olyan mondanivalóm nincs a szeretetről, amit Jézus ne mondott volna el, és azt tapasztaltam, hogy a pszichológiai szakirodalomnak sem nagyon van." (Mérö 2010: 71-72)

${ }^{20}$ Schultz, H. (2012) Sztárkávéház. A Starbucks története csészéröl csészére. Budapest, HVG Könyvek. 
Eszmefuttatása alapján a beszélő azt a propozíciót akarja kifejezni, amely a befogadó számára a leginkább releváns, s ez érthető, hiszen ezzel érhető el a befogadó fél felé megfogalmazott üzenet minél teljesebb átadása. A mémek terjedésével is összhangba hozható konklúziója, miszerint a kölcsönös tudás nem a feltétele, hanem a következménye a megértésnek, hiszen a befogadó fél jelentéstulajdonító müveletei nagyban meghatározzák azt. Ahogy Pataki is az Én-t a társadalmi és a társas folyamatok eredményeképpen ontogenezissel kifejlődő pszichikai alakzatnak tekinti: az „identitás sajátos, hierarchikus elv szerint szerveződő kognitív struktúra, amelynek elemei részben elsajátításuk egymásra szerveződése, részben énközeliségük, egzisztenciális fontosságuk szerint más és más személyes jelentéssel és értékkel rendelkeznek... a hierarchiát a személyes fontosság élménye $\mathrm{s}$ az egyén aktív jelentéstulajdonítási műveletei teremtik meg." (Pataki 2002: 518).

Dawkins 1976-ban Az önző gén címü könyvében írt először a mémekröl. Könyvét, ahogy írja a harmincéves kiadás előszavában 2006-ban, egyfajta polgárpukkasztásnak gondolta: vett egy nagy levegőt, és le merte írni azt, amit gondolt. 2006-ban Dawkins arról ír már, hogy maga is meglepődött azon, hogy müve három évtized alatt tananyaggá vált. A téma ma már több mint tananyag: folyamatosan változnak a memetikával kapcsolatos álláspontok, és eközben megjelent az internetes mém fogalma, ami jelentősen eltér a dawkinsi koncepciótól. Elsősorban a bottom-up terjedő, mémnek nevezett online tartalmakra vonatkozik: a jelenség bemutatása önálló tanulmányt igényelne, ezért ezen írásban csak az említés szintjén érdemes jelezni a trend tagadhatatlan fontosságát.

A Wikipédia szerint az internetes mém kifejezése neologizmus, mely: olyan kifejezést vagy fogalmat takar, ami divatszerüen terjed embertől emberig az interneten. A kifejezés utal a mémekre, valójában digitális fájl vagy hiperhivatkozás terjesztése egyik személytől a többiek felé az internet lehetőségein (e-mail, blog, kapcsolatépítő oldalak, azonnali üzenetküldő szolgáltatások stb.) keresztül. A tartalom lehet szólás, vicc, módosított vagy módosítatlan kép, egy egész weboldal, videoklip vagy animáció stb. Állandósulhat, de változhat is az idők során, a rá irányuló kommentárok hatására.

$\mathrm{Az}$ internetes mémeket többen müvészeti formának tartják, hiszen egyre nő az ezeket gyüjtő és népszerüsítő, terjedésüket szolgáló weboldalak száma. Ismertebb internetes mémnek számít a Sün!, a Hummer terepjáró a befagyott Balatonban, Szalacsi Sándor, Gordon Ramsay megmondja, Hungaro mém, Tibi atya, Sanyi a bagoly stb.

Egyes internetes szolgáltatások, például a snopes.com, az urban dictionary vagy a magyar nyelvü Urbanlegends.hu listákat tartanak fenn, melyek segítségével az interneten gyakran elöforduló állítások valóságtartalmát, forrását ellenőrizni lehet.

Napjainkban 85 millió Google-találat van a meme-re, több mint 70 millió az internet meme-re, és közel 300 ezer a memetics-re, a magyar mémesedik szóra pedig 3850. Dawkins szerint az internetes mémek másképp hagynak nyomot, jelentőségüket ő maga is elismeri: „Internet memes carry an additional property that ordinary memes do not - Internet memes leave a footprint in the media through which they propagate (for example, social networks) that renders them traceable and analyzable."

\section{IRODALOM}

Atran, S. (2001): A cheater detection module? Dubious interpretations of the Wason Selection Task and logic. Evolution and Cognition, Vol. 7.183-193.

Babbie, E. (2001) A társadalomtudományi kutatás gyakorlata. Budapest, Balassi Kiadó.

Banaji, M. (2003) Rejtőzködö attitüdök és sztereotípiák. Budapest, Osiris Kiadó. 
Barabási, A. L. és Albert, R. (2001) Statistical Mechanics of Complex Networks. Reviews of Modern Physics, Vol. 74. 47-97.

Barabási A. L. (2003) Behálózva - a hálózatok új tudománya. Budapest, Magyar Könyvklub.

Bereczkei, T. (2009) Az erény természete. Önzetlenség, együttmüködés, nagylelküség. Budapest, Typotex.

Béres, I. és Horányi, Ö. (2001szerk.) Társadalmi kommunikáció. Budapest, Osiris. http://www.communicatio.hu/konyvek/beres_horanyi_tarsadalmi_kommunikacio/tartalom (olvasva: 2012. július 7.)

Blackmore, S. (2001) A mémgépezet. Budapest, Magyar Könyvklub.

Broder, A., Kumar, R., Maghoul, F., Raghavan, P., Rajagopalan, S., Stata, R., Tomkins, A., Wiener, J. (2000) Graph structure in the web (on-line). http://www9.org/w9cdrom/160/160.html (olvasva: 2012. április 25.)

Bruner, Jerome (1996) Actual Minds, Possible Worlds. Cambridge, Harvard University Press.

Burt, R. S. (1982) Toward a Structural Theory of Action - Network Models of Social Structure. Perception, and Action. New York, Academic Press.

Csányi, G. és Szendröi, B. (2004) Structure of a Large Social Network. Physical Review E (Statistical, Nonlinear, and Soft Matter Physics), Vol. 69, 036131.

Csányi, V. (1979) Evolúciós rendszerek - Az evolúció általános elmélete. Budapest, Gondolat.

Csányi, V. (1999) Az emberi természet - Humánetológia. Budapest, Vince Kiadó.

Dawkins, R. (1976) The Selfish Gene. Oxford, Oxford University Press.

Dawkins, R. (1986) Az önzö gén. Budapest, Gondolat Kiadó.

Dawkins, R. (1989) A hóditó gén. Budapest, Gondolat Kiadó.

Dawkins, R. (1993) Viruses of the mind. In: B. Dalhbom (ed.) Dennett and His Critics: Demystifying Mind. Cambridge, Mass., Blackwell.

Dennett, C. D. (1991) Consciousness Explained. London, The Penguin Press.

Dennett, C. D. (2002b) Mémek: mítoszok, félreértések és félelmek. Információs Társadalom, Vol. 2(2). 6-18.

Distin, K. (2005) The Selfish Meme - A critical reassessment. New York, Cambridge University Press.

Dunbar, R. (1996) Grooming, Gossip, and the Evolution of Language. London, Faber and Faber.

Dunbar, R. (2007) The social brain: mind, language and society in evolutionary perspective. Annual Review of Anthropology, Vol. 32. 163-181.

Festinger, L. (2000) A kognitív disszonancia elmélete. Budapest, Osiris Kiadó.

Gladwell, M. (2000) The Tipping Point. New York, Little Brown \& Company.

Granovetter, M. S. (1973) The Strength of Weak Ties. American Journal of Sociology, Vol. 78. $1360-1380$.

Horányi, Ö. (szerk.) (2003szerk.) Kommunikáció I. Válogatott tanulmányok - A kommunikatív jelenség. Budapest, General Press Kiadó. 
Horányi, Ö. (2001) A kommunikációról. In: I. Béres és Ö. Horányi (2001szerk.) Társadalmi kommunikáció (on-line). Budapest, Osiris Kiadó. http://www.communicatio.hu/ konyvek/beres_horanyi_tarsadalmi_kommunikacio/tartalom

Laland, K. és Brown, G.(2002) Sense and Nonsense - Evolutionary Perspectives on Human Behaviour. New York, Oxford University Press.

László, János (1999) Társas tudás, elbeszélés, identitás - A társas tudás modern szociálpszichológiai elméletei. Budapest, Scientia Humana-Kairosz.

László, János (2003) Moscovici és a szociálpszichológia. In: J. László (szerk.) S. Moscovici, Társadalom-lélektan. Budapest, Osiris Kiadó.

Liljeros, F. és mások (2003) Sexual networks - implications for the transmission of sexually transmitted infections. Microbes and Infections, Vol. 5. 189-196.

Mérő, László (2004a) Memetika - blöff vagy új tudomány? In: J. László, J. Kállai és T. Bereczkei (szerk.) A reprezentáció szintjei. Budapest, Gondolat Kiadó. 294-303.

Mérö, László (2004b) Az élö pénz. Budapest, Tericum.

Mérő, László (2010) Az érzelmek logikája. Budapest, Tericum.

Milgram, S. (1967) The Small World Problem. Psychology Today, Vol. 2, pp. 60-67.

Moscovici, S. (2002) Társadalom-lélektan. Budapest, Osiris.

Pataki, Ferenc (2002) Identitás-személyiség-társadalom. In: Zs. Lengyel (2002szerk.) Szociálpszichológia szöveggyüjtemény. Budapest, Osiris Kiadó. 512-529.

Pléh, Csaba (2000) A gondolatok terjedési mechanizmusai: mémek vagy fertőzések. Replika, Vol. 40, pp. 165-185.

Pléh, Csaba (2013) A megismeréstudomány alapjai - Az embertöl a gépig és vissza. Budapest, Typotex.

Rushkoff, D. (1995) Media Virus! New York, Penguin Books.

Síklaki, István (2008szerk.) Szóbeli befolyásolás. Budapest, Typotex.

Smith, E. R. és Mackie, D. M. (2001) Szociálpszichológia. Budapest, Osiris Kiadó.

Sperber, D. (2001) A kultúra magyarázata. Budapest, Osiris Kiadó.

Watts, D. J. és Strogatz, S. H. (1998) Collective Dynamics of Small World Networks. Nature, Vol. 393. 440-442. 